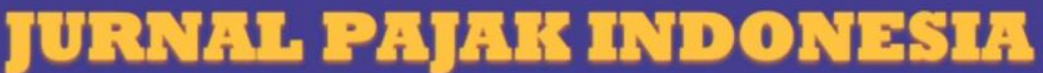

(Indonesian Tax Journal)

www.jurnal.stan.ac.id/index.php/JPI

\section{PENGHITUNGAN KREDIT PAJAK MASUKAN PKP \\ YANG MELAKUKAN PENYERAHAN YANG TERUTANG PPN DAN YANG DIBEBASKAN (STUDI PADA PDAM TIRTA PATRIOT)}

\author{
Rizqi Haniyah, \\ Politeknik Keuangan Negara STAN \\ Asqolani, \\ Politeknik Keuangan Negara STAN \\ Alamat Korespondensi: Rizqi.haniyah@pknstan.ac.id
}

INFORMASI ARTIKEL

Diterima Pertama

[16 02 2020]

Dinyatakan Diterima

[19 02 2020]

KATA KUNCI:

Pengkreditan Pajak Masukan, Air Bersih, Pajak Pertambahan Nilai, Barang Kena Pajak Dibebaskan.

KLASIFIKASI JEL:

H250 Business Taxes and Subsidies including sales and value-added (VAT).

\section{ABSTRAK}

The company of Regional Drinking Water (PDAM) Tirta Patriot has two types of income, clean water supply service income and non-water income. Clean water is a taxable good that is exempt from the imposition of value-added tax, according to Peraturan Pemerintah Nomor 40 Tahun 2015. On the other hand, the company still has to collect the VAT from its non-water income. The different standards caused issues related to input tax, which should not be credited entirely because the resources also used by taxable goods submission, but the amount cannot be certainty identified. Therefore, the amount of input tax credit for the value-added tax reporting should be calculated using the particular guidelines governed by the Ministry of Finance Regulation No. 135/PMK. 011/2014. This research uses qualitative methods by exploring data and facts about the case of tax crediting of inputs using primary data, i.e., interviews. The data collection techniques used in the study are library research and field research.

PDAM Tirta Patriot memiliki dua jenis penghasilan yaitu layanan penyediaan air bersih dan penghasilan dari selain air bersih. Air bersih merupakan Barang Kena Pajak yang dibebaskan dari pengenaan Pajak Pertambahan Nilai sesuai Pemerintah Nomor 40 Tahun 2015. Disamping itu, perusahaan juga memiliki penghasilan lain yang secara ketentuan perpajakan terutang pemungutan PPN. Adanya kebijakan pembebasan PPN terhadap air minum, menyebabkan Pajak Masukan seharusnya tidak dapat dikreditkan seluruhnya karena terdapat penyerahan yang terutang pajak, namun tidak dapat diketahui dengan pasti berapa besar jumlah Pajak Masukan yang dapat dikreditkan. Oleh sebab itu, jumlah Pajak Masukan yang dapat dikreditkan untuk penyerahan yang terutang pajak dihitung dengan menggunakan pedoman yang diatur dengan Peraturan Menteri Keuangan No. 135/PMK.011/2014. Penelitian ini menggunakan metode kualitatif yang ditujukan untuk memperoleh data dan fakta tentang kasus pengkreditan Pajak Masukan dan menggunakan data primer yaitu wawancara. Teknik pengumpulan data yang digunakan adalah studi kepustakaan dan studi lapangan. 


\section{PENDAHULUAN}

\subsection{Latar Belakang}

Air merupakan kebutuhan dasar dalam kehidupan masyarakat. Air memiliki beberapa fungsi penting yakni fungsi ekologis, fungsi ekonomis, serta fungsi sosial. Fungsi sosial menempatkan air sebagai barang publik yang mengutamakan pemanfaatan yang berlandaskan kepentingan umum dibandingkan pemanfaatan secara privat (Amanda, 2013). Terkait dengan adanya krisis air bersih, dari awal pemerintah berusaha mengatasi krisis penyediaan dan pendistribusian air bersih dengan membentuk PDAM (Perusahaan Daerah Air Minum) di sejumlah Kabupaten/Kota (Ika, 2013). Sejalan dengan hal tersebut, pemerintah pusat bersama dengan pemerintah daerah membangun suatu sistem dalam usaha menjamin ketersediaan air untuk memenuhi kebutuhan masyarakat. Pengembangan Sistem Penyediaan Air Minum (SPAM) ditujukan untuk mendistribusikan air minum yang berkualitas dengan harga terjangkau.

Untuk memenuhi kebutuhan air minum di daerah, pemerintah daerah daerah dapat membentuk Badan Usaha Milik Daerah (BUMD) Perusahaan Daerah Air Minum (PDAM). PDAM yang bermodalkan kekayaan daerah yang dipisahkan kemudian harus dikelola dengan prinsip usaha pada umumnya (good corporate governance) agar dapat menghasilkan air bersih untuk masyarakat dengan biaya yang efisien, berkelanjutan, dan memberikan pelayanan dengan cakupan yang makin luas. Selain melakukan pelayanan publik, dengan penerapan good corporate governance, BUMD termasuk PDAM diharapkan dapat memberikan manfaat bagi perkembangan perekonomian daerah dan juga untuk memperoleh laba dan berkontribusi pada pendapatan asli daerah sebagaimana tersirat pada UU Nomor 23 tahun 2014 tentang Perusahaan Daerah.

Secara garis besar, proses PDAM menghasilkan air bersih bermula dari PDAM membeli air baku dari Perusahaan Umum Jasa Tirta. Pengertian air baku sebagaimana disebutkan dalam Peraturan Pemerintah 122 Tahun 2015 tentang SPAM adalah air yang berasal dari sumber air permukaan, air tanah, air hujan dan air laut yang memenuhi baku mutu tertentu sebagai air baku untuk air minum. Air baku tersebut kemudian dialirkan melalui pipa ke Water treatment Plant (WTP) PDAM untuk diproduksi menjadi air bersih sehingga memenuhi syarat kesehatan melalui proses penyaringan dan pengendapan kotoran. Selanjutnya proses penyehatan air dimulai dengan pencampuran bahan kimia, dan kemudian pengadukan lambat dan cepat agar bahan kimia merata. Selanjutnya adalah tahap sedimentasi atau pengendapan partikel-partikel hasil proses kimia sebelumnya yang kemudian disaring (sand filter) menjadi air bersih. Terakhir, pemberian desinfektan untuk menghilangkan bau dan rasa pada air bersih. Air yang telah dipastikan bersih tersebut ditampung di reservoir sebelum mengalir ke para konsumen (Hafni, 2012).
Berdasarkan penjelasan tersebut, wajar apabila masyarakat membayar dengan tarif ditetapkan untuk menikmati air dari PDAM. Pembayaran tersebut untuk menjaga keberlangsungan PDAM dalam memproduksi dan menyalurkan air bersih kepada masyarakat. Air bersih tidak dapat dimanfaatkan sebagai barang publik murni, karena air tersebut merupakan barang dengan nilai tambah. Terdapat usaha untuk memberikan nilai kepada sumberdaya air melalui berbagai mekanisme sehingga sampai di tangan konsumen dan aman untuk diminum atau digunakan (Esanawati, 2009). Namun tarif air bersih yang diberlakukan harus affordable dan dapat dijangkau oleh daya beli masyarakat. Disisi lain tarif tersebut juga harus dapat mencapai titik impas untuk menutupi biaya produksi dan memberikan keuntungan bagi perusahaan (Amanda, 2013).

Sesuai dengan sistem pemungutan pajak yang berlaku di Indonesia, Wajib Pajak diberi wewenang untuk menentukan sendiri besarnya pajak yang terutang berdasarkan konsep self assessment system (Mardiasmo, 2018). Keberadaan PDAM sebagai badan usaha di bawah pemerintah daerah tidak lepas dari kewajiban perpajakan baik Pajak Penghasilan (PPh) maupun Pajak Pertambahan Nilai (PPN). Terhadap wajib pajak yang telah memenuhi syarat untuk di kukuhkan sebagai Pengusaha Kena Pajak, wajib melaporkan usahanya sebelum melakukan penyerahan Barang Kena Pajak dan/atau Jasa Kena Pajak (Waluyo, 2018).

Pendapatan usaha PDAM berasal dari penyerahan barang berupa air dan penyerahan barang dan/atau jasa non air. Atas penyerahan air yang sesungguhnya merupakan kebutuhan fundamental masyarakat juga tidak lepas dari pengenaan PPN. Pada Pasal 4 UU Nomor 42 tahun 2009 tentang Perubahan Ketiga atas UU Nomor 8 Tahun 1983 tentang Pajak Pertambahan Nilai Barang dan Jasa dan Pajak Penjualan atas Barang Mewah atau UU PPN disebutkan bahwa Pajak Pertambahan Nilai dikenakan atas penyerahan Barang Kena Pajak di dalam Daerah Pabean yang dilakukan oleh Pengusaha. Sedangkan di Pasal 4A disebutkan bahwa air bersih atau air minum tidak termasuk kedalam jenis barang yang tidak dikenai Pajak Pertambahan Nilai, sehingga air bersih tersebut termasuk dalam Barang Kena Pajak (BKP).

Pemerintah menerbitkan Peraturan Pemerintah Republik Indonesia Nomor 40 Tahun 2015 tentang Penyerahan Air Bersih yang Dibebaskan dari Pengenaan Pajak Pertambahan Nilai. Fasilitas perpajakan atas penyerahan air bersih tersebut diberikan sehubungan karena air merupakan kebutuhan dasar serta berkaitan dengan tanggung jawab negara dalam menjamin pemenuhan hak rakyat atas air minum dan akses terhadap air minum. Air bersih yang dibebaskan dari PPN terdiri air bersih yang belum siap untuk diminum dan/atau air bersih yang sudah siap untuk diminum, tidak termasuk air minum dalam kemasan. Terkait dengan mekanisme pembebasan PPN terhadap penyerahan air bersih menurut Ginting menyebabkan masyarakat luas harus menanggung harga jual yang lebih besar karena membebankan PPN Masukan sebagai biaya (Ginting \& Wijaya, 2018). 
Selain melakukan penyerahan air bersih, PDAM juga melakukan penyerahan Barang dan/atau Jasa yang terutang Pajak Pertambahan Nilai. Pendapatan PDAM lainnya diantarannya pendapatan dari pembayaran administrasi pelanggan, pendapatan pendaftar baru, pendapatan pemasangan baru, penjualan air minum kemasan, pendapatan penggantian meteran dan pipa, dan penyerahan air kepada non-rumah tangga.

Jika melihat pada proses bisnis PDAM dan juga ketentuan pasal 9 ayat 5 dan 6 serta pasal 16 B ayat 3 UU PPN, pengkreditan Pajak Masukan tidak dikaitkan atas produk yang dihasilkan melainkan dikaitkan dengan penyerahan barang atau jasanya (Surya, 2014). Adanya dua jenis penghasilan yang berbeda dalam perlakuan PPN-nya mengharuskan perusahaan untuk dapat mengetahui perlakuan Pajak Masukannya. Oleh sebab itu, akan ada Pajak Masukan yang seharusnya tidak dapat dikreditkan seluruhnya karena adanya penyerahan yang terutang PPN dan ada yang memperoleh fasilitas dibebaskan PPN-nya.

Untuk menghitung besarnya Pajak Masukan yang dapat dikreditkan, dihitung dengan menggunakan data total penyerahan dalam 1 (satu) tahun buku, bukan berdasarkan bulanan sebagaimana disimpulkan dari penelitian terhadap adanya perbedaan persepsi antara wajib pajak dengan pihak kantor pajak (Kusumastuti, 2018). Sehingga menentukan pengkreditan kembali Pajak Masukan untuk penyerahan yang terutang pajak tidak dapat diketahui dengan pasti, diatur dalam Peraturan Menteri Keuangan Nomor 135/PMK.011/2014.

Berdasarkan uraian diatas, penulis melakukan penelitian studi kasus dengan mengambil judul: "PENGHITUNGAN KREDIT PAJAK MASUKAN PKP YANG MELAKUKAN PENYERAHAN YANG TERUTANG PPN DAN YANG DIBEBASKAN (STUDI PADA PDAM TIRTA PATRIOT."

\section{KERANGKA TEORI}

\subsection{PDAM sebagai Subjek Pajak Badan}

Dalam pasal 2 ayat 1 UU Nomor 36 Tahun 2008 Perubahan Keempat atas UU Nomor 7 Tahun 1983 tentang Pajak Penghasilan (UU PPh), yang menjadi subjek pajak adalah orang pribadi, warisan yang belum terbagi sebagai satu kesatuan menggantikan yang berhak, badan dan bentuk usaha tetap. Badan dalam penjelasan pasal 2 ayat 1 UU PPh adalah sekumpulan orang dan/atau modal yang merupakan kesatuan baik yang melakukan usaha maupun yang tidak melakukan usaha yang meliputi perseroan terbatas, perseroan komanditer, perseroan lainnya, badan usaha milik negara atau badan usaha milik daerah dengan nama dan dalam bentuk apa pun, firma, kongsi, koperasi, dana pensiun, persekutuan, perkumpulan, yayasan, organisasi massa, organisasi sosial politik, atau organisasi lainnya, lembaga, dan bentuk badan lainnya termasuk kontrak investasi kolektif dan bentuk usaha tetap.

PDAM merupakan badan usaha yang dimiliki pemerintah daerah yang berfungsi mendistribusikan air bersih bagi masyarakat umum melalui Sistem Penyediaan Air Minum (SPAM) dengan tujuan untuk memberikan pelayanan air minum kepada masyarakat untuk memenuhi hak rakyat atas air minum. Kebutuhan akan air ini digunakan untuk memenuhi kebutuhan hidup sehari-hari misalnya untuk keperluan minum, masak, mandi, cuci, peturasan, dan ibadah, sebagaimana diatur dalam Peraturan Pemerintah Nomor 122 tahun 2014.

\subsection{PDAM Sebagai Pengusaha Kena Pajak yang Memungut dan Melaporkan PPN}

Pendapatan PDAM sebagian besar diperoleh dari core usahanya, yaitu penjualan air bersih. Pendapatan penjualan air, baik melalui pipa maupun tangki air, diakui saat produk air telah diterima atau digunakan oleh konsumen. Selain itu, PDAM juga memperoleh pendapatan non air. Pendapatan non air yang diperoleh PDAM diakui pada saat produk atau jasa non air telah diterima atau digunakan oleh pelanggan, yang ditagihkan setiap bulan. Konsumen PDAM Tirta Patriot meliputi rumah tangga, niaga, sosial, industri, instansi pemerintah, dan lainnya. Jenis pendapatan non air menurut Permendagri Nomor 71 tahun 2016 tentang Perhitungan dan Penetapan Tarif Air Minummeliputi:

a. pendapatan sambungan baru;

b. pendapatan pemeriksaan air lab;

c. pendapatan penyambungan kembali;

d. pendapatan denda;

e. pendapatan penggantian meter rusak;

f. pendapatan penggantian pipa persil; dan

g. pendapatan non air lainnya.dan lain-lain.

Mengingat air merupakan kebutuhan strategis dan mendasar maka untuk menjamin ketersediaan air dan mendukung kebijakan pemerintah mengenai pengembangan sistem penyediaan air minum (SPAM) dibuat kebijakan yang memberikan fasilitas perpajakan atas penyerahan air bersih, yaitu dalam Peraturan Pemerintah Nomor 40 tahun 2015.

Dalam Pasal 3 Peraturan Pemerintah Nomor 40 Tahun 2015 tersebut, yang dimaksudkan dengan dengan air bersih yang dibebaskan dari PPN adalah air bersih yang belum siap untuk diminum dan/atau air bersih yang sudah siap untuk diminum. Air minum dalam kemasan bukan termasuk dalam jenis air bersih dimaksud.

Dalam Pasal 4 peraturan tersebut, disebutkan bahwa pengusaha yang melakukan penyerahan air bersih yang mendapatkan fasilitas dimaksud, wajib melaporkan usahanya untuk dikukuhkan sebagai Pengusaha Kena Pajak (PKP). Dengan demikian, dalam kegiatan penyerahan air bersih, PDAM berhak membebaskan PPN atas penjualan air bersih. Namun PDAM harus melaporkan usahanya untuk dikukuhkan sebagai PKP.

Dalam setiap penyerahan Barang Kena Pajak (BKP) dan atau Jasa Kena Pajak (JKP), PKP harus menerbitkan Faktur Pajak sesuai pasal 13 UU PPN. Mekanisme pengaturan Nomor Seri Faktur Pajak diatur dalam Per24/PJ/2012 tentang Bentuk, Ukuran, Tata Cara Pengisian Keterangan, Prosedur Pemberitahuan dalam rangka Pembuatan, Tata Cara Pembetulan atau 
Penggantian, dan Tata Cara Pembatalan Faktur Pajak. Faktur Pajak tersebut harus dibuat pada:

a. saat penyerahan Barang Kena Pajak dan/atau penyerahan Jasa Kena Pajak;

b. saat penerimaan pembayaran dalam hal penerimaan pembayaran terjadi sebelum penyerahan Barang Kena Pajak dan/atau sebelum penyerahan Jasa Kena Pajak;

c. saat penerimaan pembayaran termin dalam hal penyerahan sebagian tahap pekerjaan; atau

d. saat lain yang diatur dengan atau berdasarkan Peraturan Menteri Keuangan.

Berkaitan dengan penjualan air yang dibebaskan PPN-nya, maka Pajak Masukan terkait pengeluaran produksi air tersebut tidak dapat dikreditkan oleh PDAM, bahkan ke penyerahan barang/jasa lainnya yang dikenai PPN. Hal ini sesuai dengan Pasal 5 PP No. 40 Tahun 2015 menyebutkan bahwa Pajak Masukan atas Barang Kena Pajak dan/atau Jasa Kena Pajakyang digunakan untuk menghasilkan air bersih tidak dapat dikreditkan.

PPN Pajak Masukan yang tidak dapat dikreditkan tersebut oleh PDAM akan dibebankan sebagai biaya maupun dikapitalisasi dalam harga perolehan (Ginting \& Wijaya, 2018). Sedangkan untuk Pajak Masukan terkait pengeluaran yang berkenaan dengan penyerahan yang dipungut PPN, Pajak Masukannya dapat dikreditkan. Namun dalam suatu perusahaan tentunya akan ditemukan kesulitan memilah-milah pengeluaran berdasarkan jenis barang/jasa yang diserahkan. Maka akan ditemukan Pajak Masukan berkenaan dengan penyerahan keduanya yang harus dihitung dengan ketentuan khusus untuk jumlah Pajak Masukan yang dapat dikreditkan.

\subsection{Penghitungan Kredit Pajak Masukan Sesuai PMK Nomor 135/PMK.011/2014}

Suatu Pengusaha Kena Pajak yang selain melakukan penyerahan yang terutang PPN juga melakukan penyerahan barang strategis yang tidak terutang PPN, akan memiliki memiliki Pajak Masukan yang berasal dari pengeluaran untuk memproduksi keduanya. Sehingga Pajak Masukan yang dapat dikreditkan pada pajak keluaran penyerahan yang terutatang PPN tidak dapat diketahui dengan pasti. Sehingga, untuk menentukan jumlah Pajak Masukan yang dapat dikreditkan pada pajak keluaran penyerahan yang terutang PPN akan dihitung dengan menggunakan ketentuan khusus.

Ketentuan ini diatur dalam Peraturan Menteri Keuangan Nomor 78/PMK.03/2010 sebagaimana diubah terakhir dengan Peraturan Menteri Keuangan Nomor 135/PMK.011/2014 Tentang Pedoman Penghitungan Pengkreditan Pajak Masukan Bagi Pengusaha Kena Pajak yang Melakukan Penyerahan Yang Terutang Pajak Dan Penyerahan yang Tidak Terutang Pajak.

Pedoman penghitungan Pajak Masukan yang dapat dikreditkan digunakan rumus sebagai berikut:

$\mathrm{P}=\mathrm{PM} \times \mathrm{Z}$

dengan ketentuan:
P : adalah jumlah Pajak Masukan yang dapat dikreditkan;

PM : adalah jumlah Pajak Masukan atas perolehan Barang Kena Pajak dan/atau Jasa Kena Pajak;

Z : adalah persentase yang sebanding dengan jumlah Penyerahan yang Terutang Pajak terhadap penyerahan seluruhnya.

Penghitungan kembali Pajak Masukan yang dapat dikreditkan harus dihitung kembali paling lama pada bulan ketiga setelah berakhirnya tahun buku dengan pedoman sebagai berikut:

a. Untuk Barang Kena Pajak dan Jasa Kena Pajak yang masa manfaatnya lebih dari 1 (satu) tahun:

$$
\mathrm{P}^{\prime}=\frac{\mathrm{PM}}{\mathrm{T}} \times \mathrm{Z}^{\prime}
$$

dengan ketentuan:

$\mathrm{P}^{\prime} \quad$ : adalah jumlah Pajak Masukan yang dapat dikreditkan dalam 1 (satu) tahun buku;

PM : adalah jumlah Pajak Masukan atas perolehan Barang Kena Pajak dan/atau Jasa Kena Pajak.

T $\quad$ : adalah masa manfaat Barang Kena Pajak dan/atau Jasa Kena Pajak yang ditentukan sebagai berikut:

- untuk Barang Kena Pajak berupa tanah dan bangunan adalah 10 (sepuluh) tahun;

- untuk Barang Kena Pajak selain tanah dan bangunan dan Jasa Kena Pajak adalah 4 (empat) tahun;

Z' : adalah persentase yang sebanding dengan jumlah Penyerahan yang Terutang Pajak terhadap seluruh penyerahan dalam 1 (satu) tahun buku;

b. untuk Barang Kena Pajak dan Jasa Kena Pajak yang masa manfaatnya 1 (satu) tahun atau kurang:

$\mathrm{P}^{\prime}=\mathrm{PM} \times \mathrm{Z}^{\prime}$

dengan ketentuan:

$P^{\prime} \quad$ : adalah jumlah Pajak Masukan yang dapat dikreditkan dalam 1 (satu) tahun buku;

PM : adalah jumlah Pajak Masukan atas perolehan Barang Kena Pajak dan/atau Jasa Kena Pajak;

Z' : adalah persentase yang sebanding dengan jumlah Penyerahan yang terutang pajak terhadap seluruh penyerahan dalam 1 (satu) tahun buku.

Berdasarkan memori penjelasan pasal 16B UU PPN, salah satu prinsip yang harus dipegang teguh adalah diberlakukan dan diterapkannya perlakuan yang sama (equal treatment) terhadap semua Wajib Pajak atau kasus-kasus dalam bidang perpajakan yang pada hakikatnya sama dengan berpegang teguh pada ketentuan peraturan perundangan (Santoso, 2019).

\subsection{Sanksi Terkait Kewajiban Perpajakan PKP}

Ada berbagai sanksi yang dapat dikenakan bila Wajib Pajak tidak menjalankan kewajibannya sebagaimana aturan yang berlaku. Salah satu sanksi yang dapat dikenakan adalah tidak membuat Faktur Pajak atau membuat Faktur Pajak, tetapi tidak tepat waktu diatur dalam pasal 14 ayat 4 UU Nomor 28 Tahun 2007 tentang Ketentuan Umum dan Tata Cara 
Perpajakan (UU KUP). Terhadap pelanggarantersebut, selain wajib menyetor pajak yang terutang, juga dikenai sanksi administrasi berupa denda sebesar $2 \%$ (dua persen) dari Dasar Pengenaan Pajak.

Dalam hal Wajib Pajak membetulkan sendiri Surat Pemberitahuan Masa yang mengakibatkan utang pajak menjadi lebih besar, kepadanya dikenai sanksi administrasi berupa bunga sebesar 2\% (dua persen) per bulan atas jumlah pajak yang kurang dibayar, dihitung sejak jatuh tempo pembayaran sampai dengan tanggal pembayaran, dan bagian dari bulan dihitung penuh 1 (satu) bulan sebagaimana diatur dalam pasal 8 UU KUP. Sedangkan di pasal 9 UU KUP, apabila terjadi pembayaran atau penyetoran pajak yang dilakukan setelah tanggal jatuh tempo pembayaran atau penyetoran pajak, dikenai sanksi administrasi berupa bunga sebesar 2\% (dua persen) per bulan yang dihitung dari tanggal jatuh tempo pembayaran sampai dengan tanggal pembayaran, dan bagian dari bulan dihitung penuh 1 (satu) bulan.

Selain itu, terdapat peraturan tentang sanksi sanksi lainnya berhubungan dengan pelaporan SPT Masa PPN pada pasal 7 UU KUP tersebut. Apabila SPT Masa PPN tidak disampaikan dalam jangka waktu yang telah ditentukan, maka akan dikenakan sanksi administrasi berupa denda lima ratus ribu rupiah.

\section{METODE PENELITIAN}

\subsection{JenisPenelitian}

Jenis penelitian yang akan diterapkan adalah penelitian kualitatif dengan studi kasus. Penelitian Studi kasus adalah desain penelitian yang dapat digunakan di banyak bidang, terutama untuk melakukan evaluasi. Metode ini membangun analisis mendalam atas suatu kasus, program, peristiwa, kegiatan, proses, meneliti individual atau suatu kelompok orang (Creswell \& Creswell, 2017).

\subsection{DesainPenelitian}

Penelitian ini dilakukan dengan motede kualitatif antara lain data primer berupa wawancara. Pada tahapan ini, peneliti melakukan pengumpulan data melalui teknik sebagai berikut:

a) Data Primer

Data Primer adalah data yang diperoleh langsung dari sumbernya, diamati dan dicatat untuk pertama kalinya. Data tersebut diperoleh dengan menggunakan teknik wawancara dan studi lapangan. Dari data tersebut akan diperoleh gambaran umum mengenai PDAM Tirta Patriot khususnya aspek perpajakannya.

b) Data Sekunder

Data Skunder adalah data yang bukan diusahakan sendiri pengumpulannya oleh peneliti, namun merupakan data yang telah tersedia, misalnya diambil dari Biro Statistik, dokumen-dokumen perusahaan atau organisasi, surat kabar dan majalah, ataupun publikasi lainnya. Jenis data yang digunakan adalah studi literatur dan analisa dari penelitian pendahuluan. Selain itu, penelitian ini menggunakan data laporan-laporan yang bersumber dari perusahaan PDAM Tirta Patriot terbatas untuk menyusun simulasi penghitungan pajak Khususnya PPN.

\subsection{Metode PengumpulanData}

Pengumpulan data merupakan proses pengadaan untuk keperluan penelitian. Pengumpulan data adalah langkah yang sangat penting dalam rangkaian penulisan penelitian agar dapat menghasilkan penelitian yang dapat dipertanggung jawabkan sehingga data yang diperoleh adalah data yang benar. Metode yang digunakan dalam pengumpulan data tersebut adalah:

A. Interview

Interview merupakan teknik pengumpulan data dalam metode survey yang menggunakan pertanyaan secara lisan kepada subyek penelitian. Interview tersebut berupa pertanyaan-pertanyaan yang ditunjukan kepada pegawai bagian Akuntansi dan Perpajakan. Dari hasil interview ini penulis memperoleh penjelasan tentang sistem dan prosedur penghitungan Pajak Pertambahan Nilai atas sambungan air bersih yang terjadi pada PDAM Tirta Patriot.

\section{B. Observasi}

Observasi yaitu proses pencatatan pola perilaku subyek (orang), obyek (benda) atau kejadian yang sistematik tanpa adanya pertanyaan atau komunikasi dengan individu-individu yang diteliti. Kegiatan observasi dilakukan dengan cara mengamati proses pelaksanaan prosedur penghitungan dan pemungutan Pajak Pertambahan nilai atas sambungan baru air bersih di PDAM Tirta Patriot.

C. Studi Pustaka

Studi Pustaka adalah penelitian mempelajari buku-buku yang berhubungan dengan kegiatan penelitian yang digunakan sebagai kerangka teori dan perbandingan dengan yang dilakukan di lapangan.

\section{HASIL PENELITIAN}

\subsection{Analisis Klasifikasi Pendapatan PDAM Tirta Patriot Berdasarkan Pengenaan PPN}

PDAM adalah salah satu Badan Usaha Milik Daerah (BUMD) yang bergerak dibidang pengolahan dan distribusi air bersih bagi masyarakat. Sebagai perusahaan daerah, PDAM memiliki dua tujuan yaitu memenuhi kebutuhan masyarakat dan mencari keuntungan. Komposisi kepemilikan saham PDAM Tirta Patriot dapat dilihat di table berikut:

Tabel 1: Komposisi Kepemilikan Saham PDAM Tirta Patriot

\begin{tabular}{|c|l|r|}
\hline No. & \multicolumn{1}{|c|}{ Nama } & \multicolumn{1}{c|}{ Saham } \\
\hline 1 & Kekayaan Pemerintah Pusat & $7.46 \%$ \\
\hline 2 & Penyertaan Pemerintah Kota Bekasi & $92.54 \%$ \\
\hline & & $100.00 \%$ \\
\hline
\end{tabular}

(Sumber: Rencana Kerja dan Anggaran Tahun 2018)

PDAM Tirta Patriot yang merupakan badan usaha milik daerah yang memenuhi syarat untuk mendaftarkan sebagai subjek pajak badan sebagaimana diatur dalam penjelasan pasal 2 ayat 1 UU PPh. PDAM Tirta Patriot telah mendaftarkan dan memperoleh NPWP sehingga dapat melaksanakan hak dan kewajiban perpajakannya. 
Berdasatkan sifat pengenaan atas PPN nya, PDAM mempunyai dua jenis sumber pendapatan. Pendapatan air merupakan pendapatan atas pengaliran air ke rumah tangga, sedangkan pendapatan non air adalah pendapatan yang diperoleh selain atas pendapatan penjualan air bersih yang atas penyerahannya dikenakan PPN. Pendapatan usaha PDAM Tirta Patriot 2017-2018 ada pada tabel berikut:

Tabel 2: Pendapatan Tahun 2017-2018

\begin{tabular}{|c|l|c|c|}
\hline No. & Jenis Pendapatan & $\mathbf{2 0 1 8}$ & $\mathbf{2 0 1 7}$ \\
\hline 1 & Pendapatan Air & $90,84 \%$ & $91.25 \%$ \\
\hline 2 & Pendapatan Non Air & $9.16 \%$ & $8.75 \%$ \\
\hline 3 & Pendapatan Kemitraan & $0.00 \%$ & $0.0 \%$ \\
\hline 4 & Pendapatan Air Limbah & $0.00 \%$ & $0.0 \%$ \\
\hline & & $100 \%$ & $100 \%$ \\
\hline
\end{tabular}

(Sumber: Laporan Keuangan Tahun 2018)

Dalam Pasal 4 PP No. 40 Tahun 2015 disebutkan bahwa pengusaha yang melakukan penyerahan air bersih wajib melaporkan usahanya untuk dikukuhkan sebagai Pengusaha Kena Pajak (PKP). Dalam hal ini PDAM Tirta Patriot telah dikukuhkan sebagai PKP.

Salah satu kewajiban sebagai PKP adalah menerbitkan Faktur Pajak. Faktur Pajak harus diterbitkan setiap kali ada penyerahan Barang Kena Pajak (BKP) dan atau Jasa Kena Pajak (JKP) sebagaimana diatur dalam pasal 13 UU PPN. Penyerahan air bersih memenuhi syarat dalam Peraturan Pemerintah nomor 40 tahun 2015 tentang Penyerahan Air Bersih yang dibebaskan dari pengenaan PPN sebagai penyerahan yang memperoleh fasilitas dibebaskan. Terhadap pendapatan tersebut, PDAM akan menerbitkan faktur dengan kode faktur 08. Kode tersebut adalah untuk kelompok barang strategis, termasuk air, sebagaimana diatur dalam PER-24/PJ/2012. Kriteria air bersih dalam Peraturan tersebut dibagi atas air bersih yang belum siap untuk diminum dan air bersih yang sudah siap untuk diminum (tidak termasuk air minum kemasan).

Penghasilan PDAM selain air bersih merupakan barang serta Jasa Kena Pajak yang merupakan bagian objek PPN. Berdasarkan laporan keuangan PDAMTirta Patriot, jenis penghasilan non air perusahaan dan persentase penerimaannya adalah sebagai berikut.

Tabel 3: Persentase Penerimaan Non-Air Tahun 2018

\begin{tabular}{|c|l|r|}
\hline No. & \multicolumn{1}{|c|}{ Sumber Pendapatan } & \multicolumn{1}{c|}{$\%$} \\
\hline 1 & Jasa Administrasi & $51,86 \%$ \\
\hline 2 & Pendaftaran & $1.02 \%$ \\
\hline 3 & Perencanaan & $1.07 \%$ \\
\hline 4 & Penyambungan - Standar & $24.33 \%$ \\
\hline 5 & Pendapatan Sewa Instalasi & $0.00 \%$ \\
\hline 6 & Pendapatan Pemeriksaan Air Lab & $0.00 \%$ \\
\hline 7 & Penyambungan Kembali & $0.60 \%$ \\
\hline 8 & Pendapatan Denda & $20.76 \%$ \\
\hline 9 & Pemeriksaan Inst. Pelanggan & $0.00 \%$ \\
\hline 10 & Penggantian Meter Rusak & $0.36 \%$ \\
\hline 11 & Penggantian Pipa Persil & $0.00 \%$ \\
\hline 12 & Pendapatan Non Air Lainnya & $0.00 \%$ \\
\hline & \multicolumn{2}{|c|}{} \\
\hline
\end{tabular}

(Sumber: Laporan Keuangan Tahun 2018)
Untuk itu, PDAM yang telah dikukuhkan sebagai PKP memiliki kewajiban memungut BKP serta JKP selain air bersih tersebut, ketentuan atas pendapatanpendapatan selain pendapatan penjualan air bersih atas penyerahan BKP tetap mengikuti pemungutan PPN pada umumnya.

Untuk penyerahan BKP atau JKP selain air bersih menggunakan Faktur Pajak dengan kode faktur 01 untuk penyerahan BKP dan/atau JKP yang terutang PPN dan PPN-nya dipungut oleh PDAM yang melakukan penyerahan BKP dan/atau JKP. Sedangkan penyerahan kepada pemungut yang memenuhi syarat tertentu, digunakan kode faktur 02 atau 03.

Selain itu ada PDAM Tirta Patriot memiliki potensi pendapatan usaha lainnya yang diproyeksikan belum menghasikan sampai tahun 2018. Pendapatan dari kemitraan antara lain dapat berupa pendapatan royalti, pembagian pendapatan, pembagian produksi, pembagian keuntungan, atau berupa deviden. Kemudian terdapat potensi pendapatan dari pengolahan air limbah, antara lain retribusi limbah, atau pendapatan lain terkait pengolahan limbah. Sedangkan pendapatan di luar usaha PDAM dapat dilihat pada tabel dibawah ini:

Tabel 4: Pendapatan PDAM Tirta Patriot Lainnya

\begin{tabular}{|r|l|r|}
\hline No. & \multicolumn{1}{|c|}{ Sumber Pendapatan } & \multicolumn{1}{c|}{$\%$} \\
\hline & PENDAPATAN LAIN-LAIN & \\
\hline 1 & Bunga Deposito & $14.59 \%$ \\
\hline 2 & Jasa Giro & $11.79 \%$ \\
\hline 3 & Penjualan Barang Bekas & $0.00 \%$ \\
\hline 4 & Keuntungan Penjualan Aktiva Tetap & $0.56 \%$ \\
\hline 5 & Valas/Reksadana & $0.00 \%$ \\
\hline 6 & Penerimaan Piutang yg Dihapuskan & $0.00 \%$ \\
\hline 7 & Rupa-Rupa Pendapatan & $73.07 \%$ \\
\hline & KEUNTUNGAN LUAR BIASA & \\
\hline 1 & Penghapusan Bunga Pinjaman & $0.00 \%$ \\
\hline 2 & Penghapusan Hutang & $0.00 \%$ \\
\hline 3 & Barang-Barang Ditemukan & $0.00 \%$ \\
\hline & & $100.00 \%$ \\
\hline
\end{tabular}

(Sumber: Rencana Kerja dan Anggaran Perusahaan Tahun 2018)

Hasil dari pembahasan tersebut dapat disimpulkan terkait penyerahan yang dilakukan oleh PDAM adalah sebagai berikut:

Tabel 5: Jenis Pendapatan Usaha Lainnya

\begin{tabular}{|l|l|l|}
\hline No. & \multicolumn{1}{|c|}{ Jenis Penghasilan } & \multicolumn{1}{|c|}{$\begin{array}{c}\text { Aspek } \\
\text { Perpajakan }\end{array}$} \\
\hline 1. & Pendapatan Penjualan Air & BKP Dibebaskan \\
\hline 2. & Pendapatan Non-Air & $\begin{array}{l}\text { BKP/Terutang } \\
\text { PPN }\end{array}$ \\
\hline 3. & Pendapatan Kemitraan & Belum ada \\
\hline 4. & Pendapatan Limbah & Belum ada \\
\hline 5. & $\begin{array}{l}\text { Pendapatan Di Luar } \\
\text { Usaha }\end{array}$ & Non JKP \\
\hline
\end{tabular}

(Sumber: diolah penulis)

Terhadap pembelian yang terdapat Pajak Masukan, ada tiga jenis perlakuan perpajakannya, yaitu 
tidak dapat dikreditkan seluruhnya, dapat dikreditkan seluruhnya, dan dapat dikreditkan sebagian.

Sesuai pasal 16 B ayat 3 UU PPN, Pajak Masukan yang dibayar untuk perolehan Barang Kena Pajak dan/atau perolehan Jasa Kena Pajak yang atas penyerahannya dibebaskan dari pengenaan PPN tidak dapat dikreditkan. Pajak Masukan yang dibayar untuk perolehan BKP/JKP yang atas barang atau jasa yang penyerahannya terutang PPN, dapat dikreditkan.

Sedangkan di pasal 9 ayat 6 UU PPN, apabila dalam suatu Masa Pajak Pengusaha Kena Pajak selain melakukan penyerahan yang terutang pajak juga melakukan penyerahan yang tidak terutang pajak, sedangkan Pajak Masukan untuk penyerahan yang terutang pajak tidak dapat diketahui dengan pasti, jumlah Pajak Masukan yang dapat dikreditkan untuk penyerahan yang terutang pajak dihitung dengan menggunakan pedoman yang diatur dengan Peraturan Menteri Keuangan.

\subsection{Analisis Jenis Biaya PDAM Tirta Patriot Berdasarkan Jenis Penyerahannya}

Berdasarkan proses bisnis dan analisa terhadap biaya atau pengeluaran pada PDAM Tirta Patrio, dapat diidentifikasi jenis biaya dan penyerahan yang berkaitan dengan biaya tersebut. Biaya yang dikeluarkan dapat berkaitan dengan penjualan air sehingga Pajak Masukannya tentu tidak dapat dikreditkan, atau hanya terkait dengan penyerahan non air sehingga Pajak Masukannya dapat dikreditkan, atau terkait dengan keduanya, sehingga kredit pajak keluarannya menggunakan metode lain yang diatur oleh peraturan khusus.

Tabel 6: Jenis Biaya dan Terkait Penyerahannya

\begin{tabular}{|r|l|l|}
\hline No. & \multicolumn{1}{|c|}{ Jenis Biaya } & \multicolumn{1}{|c|}{$\begin{array}{c}\text { Terkait } \\
\text { Penyerahan }\end{array}$} \\
\hline 1 & Biaya Operasi & \\
\hline 2 & Biaya Sumber Air & Air Bersih \\
\hline 3 & Biaya Transmisi dan Distribusi & $\begin{array}{l}\text { Air Bersih dan } \\
\text { Non Air }\end{array}$ \\
\hline & & \\
\hline & Biaya Umum dan Administrasi & \\
\hline 1 & Biaya Pegawai & Air Bersih \\
\hline 2 & Biaya Kantor & Air Bersih \\
\hline 3 & Biaya Hubungan Pelanggan & Air Bersih \\
\hline 4 & $\begin{array}{l}\text { Biaya Penelitian dan } \\
\text { Pengembangan }\end{array}$ & Air Bersih \\
\hline 5 & Biaya Keuangan & Air Bersih \\
\hline 6 & $\begin{array}{l}\text { Biaya Pemeliharaan Aktiva } \\
\text { Tetap }\end{array}$ & Air Bersih \\
\hline 7 & $\begin{array}{l}\text { Biaya Penyisihan dan } \\
8\end{array}$ & Rupa-Rupa Biaya Umum \\
\hline
\end{tabular}

(Sumber: Data diolah penulis)

Dari hasil table diatas, dapat disimpulkan bahwa biaya instalasi transmisi dan distribusi adalah biaya yang digunakan untuk menghasilkan pendapatan air dan non air, sehingga, kredit Pajak Masukan atas pengeluaran tersebut nantinya akan dilakukan perhitungan kembali Pajak Masukan. Rincian atas biaya instalasi transmisi dan distribusi terdiri dari:

Tabel 7: Jenis Pendapatan Usaha Lainnya

\begin{tabular}{|c|c|c|}
\hline No. & Jenis Biaya & Keterangan \\
\hline 1 & $\begin{array}{l}\text { Saluran } \\
\text { transmisi dan } \\
\text { distribusi } \\
\text { induk }\end{array}$ & $\begin{array}{l}\text { Terdiri dari optimalisasi } \\
\text { jaringan pipa existing, } \\
\text { relokasi pipa, dan } \\
\text { penggantian pipa yang bocor } \\
\text { yang merupakan bagian dari } \\
\text { penjualan air. }\end{array}$ \\
\hline 2 & Pipa Dinas & $\begin{array}{l}\text { Pengadaan pipa SL baru dan } \\
\text { penggantian pipa dinas untuk } \\
\text { pelanggan, merupakan } \\
\text { bagian dari penjualan air dan } \\
\text { penghasilan pemasangan } \\
\text { pipa baru. }\end{array}$ \\
\hline 3 & $\begin{array}{l}\text { Meter Air } \\
\text { Instalasi } \\
\text { Transmisi dan } \\
\text { Distribusi }\end{array}$ & $\begin{array}{l}\text { Pengadaan water meter } \\
\text { induk, water meter dan } \\
\text { aksesoris pasang baru, dan } \\
\text { penggantian meter rusak, } \\
\text { merupakan bagian dari } \\
\text { penjualan air dan } \\
\text { penghasilan pemasangan } \\
\text { pipa baru. }\end{array}$ \\
\hline 4 & $\begin{array}{l}\text { Biaya Jasa } \\
\text { Eksternal }\end{array}$ & $\begin{array}{l}\text { Biaya dalam rangka kerja } \\
\text { sama dengan pihak ketiga } \\
\text { untuk pemasangan pipa baru } \\
\text { dan survey lokasi, } \\
\text { merupakan bagian dari } \\
\text { penghasilan pemasangan } \\
\text { pipa baru. }\end{array}$ \\
\hline 5 & $\begin{array}{l}\text { Biaya } \\
\text { Pemakaian } \\
\text { Alat / } \\
\text { Perlengkapan }\end{array}$ & $\begin{array}{l}\text { Penggunaan peralatan } \\
\text { pemasangan pipa seperti } \\
\text { kunci pipa, palu, obeng,tang, } \\
\text { alat ukur, dll, merupakan } \\
\text { bagian dari penjualan air dan } \\
\text { penghasilan pemasangan } \\
\text { pipa baru. }\end{array}$ \\
\hline
\end{tabular}

(Sumber: Data diolah penulis)

Perhitungan kembali Pajak Masukan sebagaimana diatur dalam pasal 9 ayat 6 UU PPN diatur dalam Peraturan Menteri Keuangan No 135/PMK.011/2014 tentang Pedoman Penghitungan Pengkreditan Pajak Masukan Bagi Pengusaha Kena Pajak dan Penyerahan yang Tidak Terutang Pajak. Menurut ketentuan PMK tersebut, Pajak Masukan khususnya yang terkait dengan pembebanan pipa dan aksesoris saluran transmisi dan distribusi yang telah dikreditkan tersebut dilakukan perhitungan kembali Pajak Masukan paling lambat 3 bulan setelah akhir tahun dan setelah diketahui jumlah masing-masing penyerahan air dan non air.

\subsection{Simulasi Penghitungan Kredit Pajak Masukan}

Pada table 1 diketahui bahwa persentase pendapatan dengan komposisi $90.84 \%$ berasal dari pendapatan air dan $9.16 \%$ untuk pendapatan non air. Mengacu pada PMK 135/PMK.011/2014 tersebut, maka penghitungan kembali Pajak Masukan yang dapat 
dikreditkan untuk tahun buku 2018 dapat dilakukan paling lambat pada Masa Pajak Maret 2019.

Dari data laporan keuangan dan kebijakan penyusutan asset tetap, pengkreditan Pajak Masukan dilakukan dengan menggunakan pedoman penghitungan dibedakan menjadi 2 yaitu:

a) Untuk Barang Kena Pajak dan Jasa Kena Pajak yang masa manfaatnya lebih dari 1 (satu) tahun, Pajak Masukan PDAM bersumber dari transaksi sebagai berikut:

1. Pembelian Pipa Retikulasi

2. Pembelian Water Pump

3. Pembelian Perlengkapan dan Alat

Berikut contoh perhitungan kembali Pajak Masukan yang dapat dikreditkan dengan menggunakan pedoman perhitungan:

Pada bulan April 2018 terdapat pembelian pipa retikulasi Rp 10.000.000.000, dengan jumlah Pajak Masukan atas pembelian pipa retikulasi sebesar Rp 1.000.000.000. Apabila berdasarkan perkiraan awal, sebelum diketahui persentase actual di akhir tahun, diperkirakan persentase rata-rata jumlah penyerahan yang terutang pajak terhadap penyerahan seluruhnya adalah sebesar $10 \%$, maka Pajak Masukan yang dapat dikreditkan untuk Masa April 2018 dihitung dengan cara berikut:

10\% x Rp 1.000.000.000 = Rp 100.000.000;

Jumlah Pajak Masukan atas perolehan pipa yang dikreditkan setiap tahun buku dihitung sesuai masa manfaat pipa. Untuk Barang Kena Pajak selain tanah dan bangunan dan Jasa Kena Pajak adalah 4 (empat), sehingga jumlah Pajak Masukan yang dapat dikreditkan pada tahun pertama adalah:

Rp 100.000.000; / 4tahun = Rp 25.000.000;

Selanjutnya, dimisalkan pada akhir tahun kemudian diketahui bahwa total peredaran usaha selama tahun buku 2018 yang terutang PPN sebagaimana dalam laporan diatas adalah sebesar $9 \%$ (sebagai contoh yang terjadi pada PDAM Tirta Mandiri tahun 2018), maka harus dilakukan penghitungan kembali Pajak Masukan atas perolehan pipa yang dilakukan paling lambat pada Masa Maret 2019, sebagai berikut:

$$
\begin{aligned}
& \text { Rp 1.000.000.000, } \\
& \text { 9.16\%x------------------------- = Rp22.900.000; } \\
& 4 \text { tahun }
\end{aligned}
$$

Sehingga, Pajak Masukan yang harus diperhitungkan kembali dengan mengurangi Pajak Masukan untuk Masa Pajak Maret 2019 adalah sebesar:

Rp 25.000.000; - Rp 22.900.000; = Rp 2.100.000;

Penghitungan kembali Pajak Masukan seperti perhitungan di atas dilakukan sampai dengan masa manfaat pipa retikulasi berakhir yaitu tahun ke-4 (keempat).

b) Untuk Barang Kena Pajak dan Jasa Kena Pajak yang masa manfaatnya 1 (satu) tahun atau kurang, Pajak Masukan PDAM bersumber dari transaksi sebagai berikut:

1. Pembelian aksesoris untuk pemasangan baru

2. Jasa pemasangan pipa dengan pihak ketiga.

Contoh penghitungannya adalah sebagai berikut:
Dimisalkan pada Bulan Mei 2018 ada pembayaran jasa pemasangan pipa baru sebesar Rp 100.000.000; dengan jumlah Pajak Masukan atas jasa tersebut sebesar $10 \%$, yaitu Rp 10.000.000. Pajak Masukan yang dapat dikreditkan untuk Masa Mei 2018 adalah sebesar Rp 10.000.000; karena dalam hal ini pendapatan atau penyerahan yang terutang PPN terkait Pajak masukan tersebut dapat diidentifikasi langsung, yaitu pemasangan pipa baru.

Dari analisa tersebut diatas dapat disimpulkan pengkreditan Pajak Masukan pada PDAM adalah sebagai berikut:

Table 8. Ikhtisar Pengkreditan Pajak Masukan berdasarkan Penyerahannya

\begin{tabular}{|l|l|l|}
\hline No. & $\begin{array}{l}\text { Pajak Masukan atas } \\
\text { Biaya Langsung Usaha }\end{array}$ & Aspek Perpajakan \\
\hline 1. & Biaya Sumber Air & PM tidak dikreditkan \\
\hline 2. & Biaya Pengolahan Air & PM tidak dikreditkan \\
\hline 3. & $\begin{array}{l}\text { Biaya Transmisi dan } \\
\text { Distribusi }\end{array}$ & $\begin{array}{l}\text { Pedoman } \\
\text { Penghitungan } \\
\text { Pengkreditan Pajak } \\
\text { Masukan }\end{array}$ \\
\hline 4. & Biaya Kemitraan & PM tidak dikreditkan \\
\hline 5. & Biaya Air Limbah & PM tidak dikreditkan \\
\hline
\end{tabular}

(Sumber: Data diolah penulis)

Terkait dengan sanksi akibat adanya pembetulan SPT Masa PPN untuk Masa sebelum tahun 2018 dengan menggunakan perhitungan kembali Pajak Masukan yang dihitung kembali sesuai dengan Peraturan Menteri Keuangan No 135/PMK.011/2014 tentang Pedoman Penghitungan Pengkreditan Pajak Masukan Bagi Pengusaha Kena Pajak dan Penyerahan yang Tidak Terutang Pajak, akan mengakibatkan terjadinya kekurangan pajak yang harus dibayar atau pengurangan jumlah lebih bayar dalam SPT Masa PPN Bulan Desember tahun yang bersangkutan.

Jika terjadi kekurangan pajak yang seharusnya disetor, akan dikenakan sanksi sebagaimana diatur dalam Pasal 8 UU KUP, yaitu sanksi administrasi berupa bunga sebesar $2 \%$ (dua persen) per bulan atas jumlah pajak yang kurang dibayar, dihitung sejak jatuh tempo pembayaran sampai dengan tanggal pembayaran, dan bagian dari bulan dihitung penuh 1 (satu) bulan.

\section{KESIMPULAN DAN SARAN}

Berdasarkan data penelitian yang berhasil diperoleh dan hasil analisis data yang dilakukan dapat disampaikan simpulan dan saran penelitian sebagai berikut:

a) Perlu adanya pemisahan yang jelas antara Pajak Masukan yang atas penyerahannya terutang PPN dan yang memperoleh fasilitas PPN dibebaskan.

b) Jika ada Pajak Masukan yang ternyata untuk penyerahan yang terutang pajak tidak dapat diketahui dengan pasti, jumlah Pajak Masukan yang dapat dikreditkan untuk penyerahan yang terutang pajak dihitung dengan menggunakan pedoman yang diatur dengan Peraturan Menteri Keuangan 
Nomor 78/PMK.03/2010 sebagaimana diubah terakhir dengan Peraturan Menteri Keuangan Nomor 135/PMK.011/2014 Tentang Pedoman Penghitungan Pengkreditan Pajak Masukan Bagi Pengusaha Kena Pajak yang Melakukan Penyerahan Yang Terutang Pajak Dan Penyerahan Yang Tidak Terutang Pajak.

c) Pada setiap awal tahun setelah diketahui secara pasti jumlah komposisi penghasilan yang terutang PPN dan tidak terutang PPN, dilakukan perhitungan kembali Pajak Masukan PPN. Terhadap implikasi yang timbul dari SPT Pembetulan Masa PPN akan menyebabkan adanya kekurangan pajak PPN yang harus disetor kembali atau berkurangnya jumlah Pajak Masukan yang dapat dikompensasikan ke masa berikutnya.

\section{IMPLIKASI DAN KETERBATASAN}

Penelitian ini memberikan implikasi pada pembetulan pelaporan SPT Masa PPN karena adanya perhitungan kembali pajak masukan yang menggunakan pedoman yang diatur dengan Peraturan Menteri Keuangan Nomor 78/PMK.03/2010 sebagaimana diubah terakhir dengan Peraturan Menteri Keuangan Nomor 135/PMK.011/2014 Tentang Pedoman Penghitungan Pengkreditan Pajak Masukan Bagi Pengusaha Kena Pajak yang Melakukan Penyerahan Yang Terutang Pajak Dan Penyerahan Yang Tidak Terutang Pajak. Penelitian ini juga memiliki keterbatasan dalam mengungkapkan data internal perusahaan dan laporan SPT Masa PPN.

\section{DAFTAR PUSTAKA (REFERENCES)}

Amanda, D. (2013). Analisis Ekonomi Pengelolaan Sumber Daya Air dan Kebijakan Tarif Air PDAM Menang Mataram. IPB Scientific Repository.

Creswell, J. W., \& Creswell, J. D. (2017). Research design: Qualitative, quantitative, and mixed methods approaches: Sage publications.

Esanawati, R. (2009). Analisis ekonomi fungsi produksi, penetapan tarif dan alokasi air minum yang efisien studi kasus : PDAM Tirta Patriot Kota Bekasi. Institute Pertanian Bogor.

Ginting, M. E. S., \& Wijaya, S. (2018). Pajak Pertambahan Nilai terhadap Penyerahan Air Bersih: Dibebaskan atau Tidak Dipungut? Paper presented at the Proseding Seminar Nasional Akuntansi.

Hafni. (2012). Proses Pengolahan Air Bersih Pada PDAM Padang. JURNAL MOMENTUM, 13(2).

Ika, S. (2013). WASPADA KRISIS AIR. In INFO RISIKO FISKAL (Vol. III). Jakarta: Pusat Pengelolaan Risiko Fiskal.

Iman Santoso, N. R. (2019). Corporate Tax Management: Mengulas upaya pengelolaan pajak perusahaan secara konseptual-praktikal: Ortax.

Kusumastuti, H. (2018). Mekanisme Penghitungan Kembali Pajak Masukan Bagi Pengusaha Kena Pajak yang Melakukan Penyerahan Terutang dan Dibebaskan daru Pajak Pertambahan Nilai. 1. doi:10.7454/jabt.v1i1.26

M Abdurrahman Surya, A. D. N., S.H., Adv. LL.M. (2014). Pengkreditan Pajak Masukan bagi Pengusaha Kena Pajak atas Perusahaan Terpadu (integrated), Kelapa Sawit yang Melakukan Penyerahan yang Terutang Pajak dan Penyerahan yang Tidak Terutang Pajak terhadap Asas Kepastian Hukum (Studi Kasus PT. Palm Lampung Persada). Retrieved from http://etd.repository.ugm.ac.id/penelitian/det ail/70467

Mardiasmo. (2018). Perpajakan. Jogjakarta: Andi Jogyakarta.

Pedoman Penghitungan Pengkreditan PajakMasukan Bagi Pengusaha Kena Pajak yang Melakukan Penyerahan yang Terutang Pajak dan Penyerahan yang Tidak Terutang Pajak., (2010).

Pedoman Penghitungan Pengkreditan PajakMasukan Bagi Pengusaha Kena Pajak yang Melakukan Penyerahan yang Terutang Pajak dan Penyerahan yang Tidak Terutang Pajak., (2014).

Peraturan Pemerintah Nomor 40 Tahun 2015 Tentang Penyerahan Air Bersih yang Dibebaskan dari Pengenaan Pajak Pertambahan Nilai, (2015a).

Peraturan Pemerintah Nomor 122 Tahun 2015 tentang Sistem Penyediaan Air Minum, Peraturan Pemerintah No 122 tahun 2015 (2015b).

Undang-Undang Nomor 23 Tahun 2014 Tentang Pemerintah Daerah, (2014).

Undang-Undang Nomor 36 Tahun 2008 tentang Perubahan Keempat atas Undang-Undang Nomor 7 Tahun 1983 tentang Pajak Penghasilan, (2009).

135/PMK.011/2014 tentang Perubahan Kedua atas Peraturan Menteri Keuangan Nomor 78/PMK.03/2010 Tentang Pedoman Penghitungan Pengkreditan Pajak Masukan Bagi Pengusaha Kena Pajak yang Melakukan Penyerahan yang Terutang Pajak dan Penyerahan yang Tidak Terutang Pajak, (2014).

Siswanto, A. D. (2013). Market Mechanism dalam Pengelolaan PDAM. Retrieved from

Undang-Undang Nomor 42 Tahun 2009 tentang Perubahan Ketiga atas Undang-Undang Nomor 8 Tahun 1983 tentang Pajak Pertambahan Nilai Barang dan Jasa dan Pajak Penjualan atas Barang Mewah, (2009).

Waluyo. (2018). Perpajakan Indonesia (Vol. 1). Jogjakarta: Salemba Empat. 
Lampiran 1: Tahap Distribusi Air Bersih PDAM

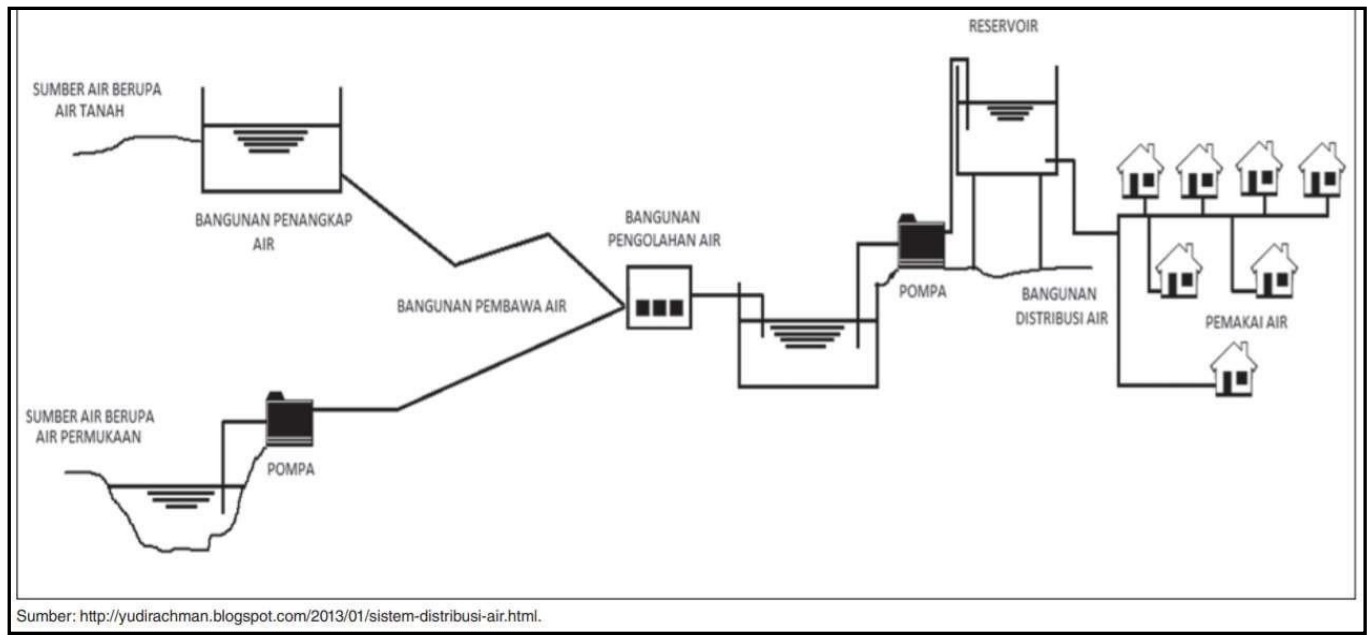

Sumber: http://yudirachman.blogspot.com/2013/01/sistem-distribusi-air.html dan Info Resiko Fiskal

(Siswanto, 2013) 